\title{
Character development based on hidden curriculum at the disaster-prone school
}

\author{
Zalik Nuryana, Suyadi \\ Department of Islamic Education, Universitas Ahmad Dahlan, Indonesia
}

\begin{tabular}{l} 
Article Info \\
\hline Article history: \\
Received May 28, 2018 \\
Revised Feb 13, 2019 \\
Accepted Apr 4, 2019
\end{tabular}

\section{Keywords:}

Disaster education

Disaster preparedness school

Hidden curriculum

\begin{abstract}
The character education development through hidden curriculum at disasterprone schools possesses its own uniqueness with challenging complexity level. Amazing character education values should clash with appalling natural phenomenon. The objective of this research is to describe the character development through hidden curriculum in the volcanology disaster-prone area of Merapi mountain. This research was conducted on July-December 2017. Qualitative approach is utilized in this research. The data collection technique is performed using participants' observation, indepth interview, and documentation. The data analysis technique is performed descriptively, interpretatively and comparatively. The result of research indicates that (1) Muhammadyah Pakem Elementary School implements hidden curriculum related to character development, (2) The Hidden Curriculum is designed to develop character and instill disaster element because it is located in disaster-prone area, (3) the implementation of hidden curriculum concerning the disaster elements at school is able to provide knowledge and skill in early age related to disaster management to reduce the numbers of victims when the disaster occurs.
\end{abstract}

Copyright $\odot 2019$ Institute of Advanced Engineering and Science. All rights reserved.

\section{Corresponding Author:}

Zalik Nuryana,

Department of Islamic Education,

Universitas Ahmad Dahlan,

Jalan Ring Road Selatan, Tamanan, Banguntapan, Bantul, Yogyakarta, Indonesia.

Email: zalik.nuryana@pai.uad.ac.id

\section{INTRODUCTION}

Muhammadiyah Pakem Elementary School is located in Ngepring Village, Purwobinangun, Pakem, Sleman,Yogyakarta which is included in volcanology disaster-prone area of Merapi mountain. As a private education institution under Muhammadyah affiliate, the school should develop multiplied character education in the disaster-prone natural situation. The multiply value is the development of character education in general and Islam-Muhammadyah values in particular. Therefore, the school uses hidden curriculum approach in the development of character education. Certainly, developing character education using hidden curriculum at disaster-prone school and action have significant difference or challenging uniqueness.

Until present, there have not been many researches on character education through hidden curriculum at disaster-prone schools. On the other hand, more various researches focus on character education success at developed schools in big cities which are free from natural disaster. In general, the existing research relates two variables, such as hidden curriculum and character education or curriculum and disaster management. There have not been many researches found using more complex variables (character education, hidden curriculum, and disaster). However, it is specific towards an objective. The following is relevant literature review.

The first is a research on hidden curriculum and character education. Some researches which are relevant to this theme is first, A Macleod's research which is entitled The hidden curriculum: Is it time to re- 
consider the concept?explain that hidden curriculum is not new. In the beginning of 1974, Vallance proposes three dimensions to help educational theorists to think critically on the hidden curriculum. The result of research is that hidden curriculum refers to one of doctoral education context which is able to build value system including the interaction of teacher-student; learning management and doctoral school administrational pattern [1]. Second, Fulya Damla Kentli explains the hidden curriculum as a socialization of schooling can be identified by the social interactions within an environment. Thus, it is in processat all times, and serves to transmit tacit messages to students about values, attitudes and principles. Hidden curriculum can reveal through an evaluation of the environment and the unexpected, unintentional interactions between teachers and students which revealed critical pedagogy [2]. Third, J. Winter and D.Cotton explains hidden curriculum as a method to maintain literacy culture in universities. The result indicates that hidden curriculum is able to help students to deconstruct the college curriculum hidden that can develop literacy continues aspects to create solution of various problems on literacy [3]. Meanwhile, M.Khairudin's research on character education which is based on culture indicates that school cultures that have become trademarks are integrative, productive, creative and innovative, qudwah hasanah, cooperative, ukhuwah, well groomed, tidy and healthy, quality-oriented, which have been implemented by the school [4]

The second is education and disaster or disaster-preparedness school. Some research concerning this theme is P. Renatana and Y. Suryono's research on required implementation evaluation and field rehearsal training for the society in disaster-prone area of Merapi mountain. The result is that the required implementation evaluation and field rehearsal training for the society indicates the trainees' behavioral changes which involve conceptual, technical and social ability. The program impact is that the trainees are able to implement independent and group risk reduction action which is obtained during the training [5]. The second is J.Cadag and Gaillard's research on integrating knowledge and action in the disaster risk deduction, contributive and participative mapping. The research result is that the local scientific knowledge integration can help reducing the disaster. The research is performed in Philippine as the flood disaster-prone area. This integration helps the stakeholders to reduce disaster risk in Philippine [6]. Further research is Ronan et all's research on the disaster preparedness for children and family; critical review. The research focus is on the disaster prevention education program. The result indicates that there has not been a program of children and family preparedness education until today. Therefore, this research will be beneficial. This research answers the basic question whether the programs offered by the government are really able to reduce the risk and increase the endurance including saving the souls and help children and family to rise up more powerful and stronger when facing a disaster [7].

The research focuses on hidden curriculum for the development of character education which contains of disaster material at Muhammadiyah Pakem Elementary School Yogyakarta. It is because education is the soul of each country in maintaining the continuous existence. The area of education to provides both challenge and opportunity. The challenge to always find new innovation to success the education in a country, an opportunity to provide wider contribution for the country through education field has wide coverage. Tilaar in her book explains that Education as a part of an effort to increase the level of human's life welfare is a part of national development. The role of education in the development of a nation especially in facing the era development has been acknowledged since the formulation of the Constitution 1945. Without a intelligent nation, it is impossible for it to have active role in the global competition among other nations [8]

Globalization era gives wide impact in various life aspects, including demand in the implementation of education. One of challenge is that the education should be able to create total competent human resource [9]. Meanwhile, disruption era is faster in the era development pattern change. Rhenald Kasali explains that technological acceleration of today to 2030, it is estimated that 2 billion employees in the world will lost their employment. It is not surprisingly that many children straightforwardly ask their parents, "mom, where do I work when I grow up?" Muscle is replaced with Robot. Gradually, technology will replace humans' power. It does not matter if it makes us more humans. For example, port porters have been replaced with crane and forklift [10]. Joko Susilo explains that the main point of learning is experience. Using this, learning humans will change from unknowing to knowing dimension, from not understanding to understanding, therefore the implication will be seen on three domain levels, such as cognitive, affective, and psychomotor [11]. By very fast era development dynamic, education should respond humanity aspect that cannot be lost, such as character, because students' education character is the reflection of national character. The demand towards learning process has higher quality as the era development and change. The learning process in every educational unit should be inspirational. The key is how the learning process is contextual and scientific so that it shapes the students' character to have scientific soul [12].

Yulia explains that Indonesia is facing various problems concerning low education quality which causes national competitiveness, both on the ASEAN regional or world level is defeated by other country. It should be responded faster through the improvement in educational level because the more dynamic change 
so that each problem which rises will influence other sectors [13]. Samsul Nizar in his research explains that Indonesia is a country which has the biggest Moslem population in the world and has ever become the "education qibla" for the country in ASEAN area. This data is a big potential for qualified Islamic education institution. However, in present reality level, there have not been many Islamic education institutions in this country which is able to aggressively respond the era development, particularly in ASEAN area. One of Islamic education institutions inability is a dichotomy education pattern. Islamic education should be synergized by performing science, language, TI, religious and cultural values transformation towards the students. Through this effort, the quality of education graduates in this country will have better competitiveness and selling power [14].

The importance of curriculum in its role as the education design at schools is expected. This disruption era demands educational institution especially Islamic education institution to innovate massively in performing education. The important thing that until nowadays has not found the solution is the character embedding on students. Schools should make students' character embedding signs in habits which are designed to be implemented by all school societies, especially the students. This unseen attitude embedding signs are called as Hidden Curriculum concept.

\section{RESEARCH METHOD}

This research was performed on July-December 2017. The research approach which is utilized is qualitative. The data collection technique is done with participants' participation, in-depth interview and documentation. The data analysis technique was performed descriptively, interpretatively, and comparatively. Schematically, the research method can be seen in the Figure 1.

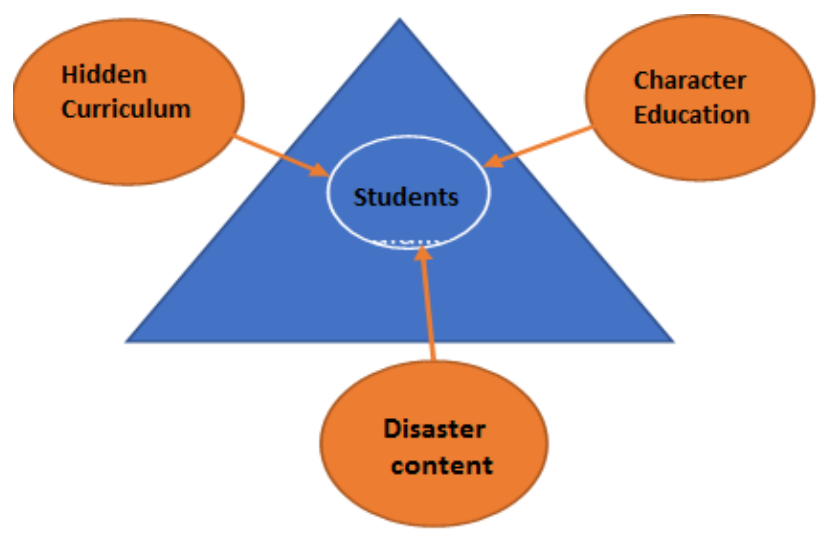

Figure 1. The schema of character education and disaster in hidden curriculum

Based on the previous figure, the research steps are first, the researcher observed Muhammadiyah Pakem Elementary School for six months, which was started June to December 2017. The researcher performed non structural interview towards the school principal, teacher, students and guardians or societies. The interview data is related to response on volcano that will erupt again and which character that will be developed so that the students will save themselves and even adapt with the disaster. Second, based on the interview data, the researcher analyzed curriculum and the hidden curriculum, how the character education development is performed in the disaster urgent situation. Third, the researcher found the document concerning the interview and curriculum data. The data which is collected is analyzed descriptively, interpretatively, and comparatively so that dept meaning is obtained.

\section{RESULTS AND ANALYSIS}

Rahmad Raharjo explains that education curriculum change in a country is an inevitability. The effort to improve education at school is a part of curriculum innovation which is adapted with era demand and development is included in Islamic religion because curriculum is not once so, thus it should be flexible, dynamic, and developable as the school condition, students' characters, societies' cultural social condition and by paying attention to local wisdom [15]. Donaldson explains that Curriculum for excellence is much more than a reform of curriculum and assessment. it is predicated on a model of sustained change which sees 
school and teachers as co creators of the curriculum [16]. In developing a curriculum, Allan C. Ornstein and Francis P. Hunkins explains that Curriculum development and the diverse curricular plans that result occur wuthin complexities of the local, regional, national, and world communities[17]. As summarized by the researcher, character should be designed and implemented at school by using this hidden curriculum. According to Jane Martin in Khairun Nisa, hidden curriculum is education side result inside or outside the school, especially result which is learnt, however, it is not explicitly attached as an objective [18]. Abdullah Idi explains that hidden curriculum is a planned and unplanned experience. Students have their own rules as a reaction towards formal curriculum such as cheating, finishing homework, becoming the class champion, attitude towards their teachers, finding effective learning strategies, etc [19].

In order to clarify the definition of hidden curriculum, Kelly explains that Some educationists speak of the hidden curriculum, by which they mean those thing which pupils learn at school because of the way in which the work of the school is planned and organized, and through, the materials provided, but which are not in themselves overtly included in the planning or even in the consciousness of those responsible for the school arrangements. Social roles, for example, are learnt in this way, it is claimed, as are sex roles and attitudes to many other aspects of living. Implicit in any set of arr angements are the attitudes and values of those who create them, and these will be communicated to pupils in this accidental and perhaps even sinister way. This factor is of course of particular significance when the curriculum is planned and imposed by government [20]. Bellack and Kliebard in Wina Sanjaya's book as cited by Sigit Wahyono explains that hidden curriculum has three dimensions that will become the research background at Muhammadyah Pakem 2 Elementary School [21], which are:

a. Hidden Curriculum can display a school relationship which involves teacher and students' interaction, class structure, all students' organization pattern as microcosms of social value system.

b. Hidden Curriculum can explain a number of implementation process inside or outside the school which involves matters that have additional value, socialization, and maintenance of class structure.

c. Hidden curriculum covers the gap level difference (intentionality) which within "the concealment" as understood by the researchers and level which is related to incidental result. Even, it is sometimes unexpected from curriculum design concerning the education social function

Therefore, hidden curriculum should be managed well. There are some factors that support the success of hidden curriculum at school. According to a research as performed by Wijayanto, the success of hidden curriculum implementation cannot be separated from the school principal's role as the manager and policy maker and implementer and all parties' support [22]. Based on the implementation of hidden curriculum at Muhammadiyah Pakem 2 Elementary School which orients on spiritual and social attitude embedding and character education content to become this school core, the formulation of character education through hidden curriculum at school which is located in disaster-probe zone makes the Elementary can be seen in Table 1 on appendix.

Based on the previous table, we can analyze that hidden curriculum as carried out at Muhammadiyah 2 Pakem Elementary School can embed character and disaster content. Therefore, the function of school in disaster-prone area can run well. The school family can have knowledge and action that minimize victims when the disaster occurs through hidden curriculum which is unseen in the school system.

\section{CONCLUSION}

Hidden curriculum is implicit signs which design the interaction of school residents that can explain the process within the school that has additional, socialization, and structural maintenance value. The implementation at school has school residents' behavior impact to have higher value. The implementation of hidden curriculum at Muhammadiyah Pakem 2 Elementary School affects the rapid school development. It is seen from positive society's response which one of indications is to increase the numbers of students from year to year. For a new school that has been built since 2013, this school has 148 students with the details : 28 students on Grade 1, 32 students on grade 2, 26 students on grade 3, 29 students on grade 4, 19 students on grade 5 , and 12 students on grade 6 .

The implementation of hidden curriculum can be used to embed students' character so the habituation which exists in the hidden curriculum structure can become a good habit for all the school residents. The understanding on the importance of hidden curriculum at school can become the formulation to be carried out on all education levels. Thus, in the future, it is expected that many formulations and concepts of character embedding at school through the Hidden Curriculum.

The next important element is that hidden curriculum also embed disaster response element, so the school is able to implement its function well, embed the students' character through hidden curriculum and provide knowledge and experience which are relevant to disaster mitigation at disaster-probe area school. 


\section{ACKNOWLEDGEMENTS}

This research is supported by Ahmad Dahlan University. We thank our colleagues from the Islamic education department UAD who provide insights and expertise that greatly assisted the research, although they may disagree with all of interpretations / conclusions from this paper. We thank Dr. Suyadi as a partner in the discussion of this hidden curriculum, and to Indah Nurcahyati as a correction of helpful scripts and comments.

We would also like to show our gratitude to Arif Rahman and Farid Setiawan as papers reviewers and to sharing their pearls of wisdom with us during the course of this research, for their comments on an early versions of the manuscript, although any errors are our own and should not tarnish the reputations of these esteemed persons.

\section{REFERENCES}

[1] A. MacLeod, "The hidden curriculum: Is it time to re-consider the concept?," Med. Teach., vol. 36, no. 6, pp. 539-540, Jun. 2014.

[2] F. D. Kentli, "Comparison of hidden curriculum theories," Eur. J. Educ. Stud., vol. 1, no. 1968, pp. 83-88, 2009.

[3] J. Winter and D. Cotton, "Making the hidden curriculum visible: Sustainability literacy in higher education," Environ. Educ. Res., vol. 18, no. 6, pp. 783-796, 2012.

[4] M. Khairudin and Susiwi, "Character Education Through School Culture Development In Integrated Islamic School Salman Al Farisi Yogyakarta (in Bahasa)," J. Pendidik. Karakter, no. 1, pp. 77-86, 2013.

[5] P. B. Renatama and Y. Suryono, "An Evaluation Of The Obliged Training And Field Practice Program For The Community Around Disaster Prone Areas Of Merapi (in Bahasa)," J. Pendidik. dan Pemberdaya. Masy., vol. 2, no. 2, pp. 192-202, 2015.

[6] J. R. D. Cadag and J. C. Gaillard, "Integrating knowledge and actions in disaster risk reduction: The contribution of participatory mapping," Area, vol. 44, no. 1, pp. 100-109, 2012.

[7] K. R. Ronan, E. Alisic, B. Towers, V. A. Johnson, and D. M. Johnston, "Disaster Preparedness for Children and Families: a Critical Review," Curr. Psychiatry Rep., vol. 17, no. 7, pp. 1-9, 2015.

[8] H. A. R. Tilaar, Several National Education Reform Agenda in the 21st Century Perspective (in Bahasa). Magelang: Penerbit Tera Indonesia, 1998.

[9] E. Y. Wijaya, D. A. Sudjimat, A. Nyoto, and U. N. Malang, "Transforming 21st century education as a demand for human resource development in the global era (in Bahasa)," Pros. Semin. Nas. Pendidik. Mat. 2016, vol. 1, pp. 263-278, 2016.

[10] R. Kasali, " This is a job that will be lost due to disruption (in Bahasa)," Rumah Perubahan, 2017. [Online]. Available: http://www.rumahperubahan.co.id/blog/2017/10/18/inilah-pekerjaan-yang-akan-hilang-akibatdisruption/.

[11] Z. Nuryana, "Learning Style As A Efforts To Increase Learning Achievements (in Bahasa)," J. Muaddib, vol. 7, no. 2, pp. 119-131, 2017.

[12] S. Slameto, "Research-based learning embody an inspirative learning (in Bahasa)," Satya Widya, vol. 31, no. 2, pp. 102-112, 2015.

[13] Yulia, "Building The Competitiveness of The Nation Through Education: Professionalism Reflection of Teachers in The Era Of Globalization (in Bahasa)," Tarb. al Awlad, vol. 4, pp. 435-444, 2008.

[14] S. Nizar, "Islamic Education At The Asean Economic Community (in Bahasa)," Akad. J. Pendidik. dan Keagamaan, vol. 11, no. 6, pp. 7-25, 2016.

[15] Z. Nuryana, "Knowledge Management sebagai Upaya Pengembangan Learning Organization di Lembaga Pendidikan Islam," LITERASI J. Pendidik., vol. 7, pp. 12-20, 2017.

[16] Dominic Wyse. et.al., Creating The Curriculum. Canada: MPG Books Group, 2013.

[17] Allan C. Ornstein and Francis P. Hunkins, Curriculum Foundation, Principles, and Issues. United States: Allyn \& Bacon is an imprint of Pearson, 2009.

[18] K. Nisa, "Hidden Curriculum: The Efforts to Improve Student Spiritual Intelligence (in Bahasa)," Lentera Pendidik. J. Ilmu Tarb. dan Kegur., vol. 12, no. 1, pp. 3-5, 2009.

[19] A. Idi, Curriculum Development, Theory and Practice (in Bahasa). Yogyakarta: Arruz Media, 2007.

[20] A. V. Kelly, The curriculum. London: SAGE Publications Limited, 2006.

[21] S. Wahyono, "Hidden curriculum innovation in entrepreneurship-based pesantren (case study at Al-Isti'anah Plangitan Pati Islamic Boarding School) (in Bahasa)," Tesis IAIN Walisongo, 2010.

[22] Wijayanto, "Women's Headmaster Leadership in Developing Hidden Curriculum (in Bahasa)," J. Manaj. Pendidik., vol. 24, no. 3, pp. 242-250, 2014.

[23] Majelis Tarjih dan Tajdid PP Muhammadiyah, Disaster's Fiqh (in Bahasa). 2015. 


\section{APPENDIX}

Table 1. The content of character and disaster education at Muhammadiyah 2 Pakem elementary school

\begin{tabular}{lll}
\hline \multicolumn{1}{c}{ Character which is developed } & \multicolumn{1}{c}{$\begin{array}{c}\text { Hidden curriculum which is } \\
\text { implemented at school }\end{array}$} & Disaster Element \\
\hline $\begin{array}{l}\text { Character which develop spiritual } \\
\text { attitude. }\end{array}$ & $\begin{array}{l}\text { Greetings and smile. It is developed everytime } \\
\text { with the teachers and employees' exemplary at }\end{array}$ & $\begin{array}{l}\text { embedding alertness and } \\
\text { responsiveness towards the disaster, such } \\
\text { Muhammadyah Pakem 2 Elementary School. } \\
\text { as asking: How did the phreatic eruption }\end{array}$ \\
& $\begin{array}{l}\text { The character is not only developed through on May 11th 2018 occur? Therefore, the } \\
\text { classroom material but also outside the students will answer using their own } \\
\text { classroom. Therefore, the communication answer which is different to the other. }\end{array}$
\end{tabular}
between teachers and students should be built for example by greeting to develop politeness and respecting character. Greeting as the symbol of proximity in Islam means to pray each other for the safety, greetings mean the beginning of natural interaction between one individual to another which also teaches to respect between the teachers and students, and smile has function to juxtapose and familiarize one to another.

Dhuha prayer in congregation. Building students' character to implement their prayer requirement. It is performed every morning before the class is started. Dhuha prayer at Muhammadyah Pakem 2 Elementary School is performed two rakaat and the reading is read jahr (loud/ pronounced). Activity is aimed to make the students of Muhammadyah Pakem 2 Elementary School are able to pronounce the shalat reading.

Tadarus al-Qur'an. This activity is performed for 15 minutes before the class is started. This activity is aimed to embed love towards alQuran. Besides building the love feeling, it also helps students to memorize $30 \mathrm{juz}$ and help memorizing the students' al-Quran reading.

Dhuhur prayer in congregation. It is implemented everyday on Dhuhur shalat time. This activity emphasizes spiritual aspect and embed human's requirements to pray towards Allah SWT.

Recitation before a meeting. This activity is specialized for the teachers and employees. The School Principal gives a mandate for the religion teacher to arrange the schedule for the teachers and employees to be a preacher which is carried out before the meeting. This activity is aimed to embed religious value towards the teachers and employees and the duty of dakwah for individuals.

Baitul Arqam (BA) is formal cadres at Muhammadiyah. This activity is prevailed for the teachers and employees of Muhammadiyah Pakem 2 Elementary School. It is held annually by following the implementation schedule as performed by the Assembly of Cadres Education of Sleman Regency. This activity is aimed to build commitment and fighting spirit at Muhammadiyah school, therefore the teachers and employees can fight all out in working at Muhammadiyah Pakem 2 Elementary School.

Character to build social attitude.

Active Duty to Join PCM. The School Principal of Muhammadiyah Pakem 2 Elementary School requires the teachers and employees to have active role in PCM

Pakem activity or other Muhammadiyah activities in their residential area. This activity is the manifestation of community service and Muhammadiyah commitment to practice

Teaching a prayer after shalat to beg for protection towards Allah to save from the disaster

Sometime the teachers ask the students to read/ repeat verses on disaster such as QS: Fussilat (41):53, al-Hadid (57):22, alNisa (4):79, al-Syura(40):30 [23]

Teaching a prayer after shalat to beg for protection towards Allah to save from the disaster

The material which is presented concerning the disaster in Islamic opinion and humanity and cooperate with Muhammadiyah Disaster Management Center (MDMC) and Lazizmu PCM Pakem

Involving the teachers and employees of Muhammadiyah Pakem 2 Elementary School to be actively involved in the activity of Branch Manager of Muhammadiyah Pakem, especially in the department of Disaster Management Center and Lazizmu.

The presented material concerning disaster in Islamic and humanity's view, cooperation with Muhammadiyah Disaster Management Canter (MDMC) and Lazizmu PCM Pakem. 


\begin{abstract}
slogan of Live Alive Muhammadiyah, don't find the live in Muhammadiyah.

Students' guardian recitation is held monthly by presenting figures on branch, region or territorial level. This activity has function to develop social attitude between the school and guardian, between the students' guardian and the other, between students' guardian, school and society.

Short Massege Send Broadcast and Whatsapp. This activity has function to strengthen hospitality of school and students' guardian. In order to respond era development, the school uses WA application to communicate with the students' guardian. Using this application, informal communication is intertwined, so the information of tausiyah $\mathrm{Wa}$ is received by the guardian immediately.
\end{abstract}

Providing education for students' guardian concerning a good news on disaster both through official web sharing such as BMKG, Merapi BLG and BPBD.

\title{
BIOGRAPHIES OF AUTHORS
}

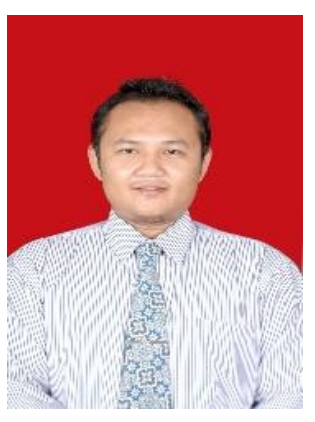

Zalik Nuryana, born in Sleman December 17, 1989. lives in Cakran, Wukirsari, Cangkringan, Sleman, Yogyakarta. Education at SD Muhammadiyah Kregan, and continued MTs and MA in Madrasah Mu'allimin Muhammadiyah Yogyakarta and graduated in 2007. completing S1 and S2 in Islamic Education Department UIN Sunan Kalijaga Yogyakarta. Now active as a lecturer in Departement of Islamic Education Faculty of Islamic Studies Ahmad Dahlan University Yogyakarta.

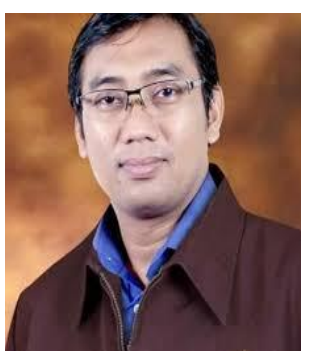

Dr. Suyadi, M.Pd.I was born in Sleman, 7 August 1982. Holds academic lector and head of Islamic education master's program Universitas Ahmad Dahlan Yogyakarta. Education at SMP N 3 Prambanan and completed master and doctoral Program at UIN Sunan Kalijaga Yogyakarta. living in Kalinangka kidul 05/13 Gayamharjo, Prambanan Sleman. 